\title{
TWO HUNDRED YEARS OF METHODISM! A BLACK THEOLOGICAL INQUIRY INTO THE HERITAGE OF METHODISM IN SOUTHERN AFRICA 1816-2016
}

\author{
Ndikho Mtshiselwa \\ Department of Biblical and Ancient Studies \\ University of South Africa \\ mtshivnn@unisa.ac.za
}

\section{ABSTRACT}

A proverb of the Yoruba people of Nigeria says: 'However far a stream flows, it never forgets its origin.' The proverb gives credence to the epochal stories of the human race, and more importantly of the Methodist people in Southern Africa. This article evaluates the history of Methodist people in Southern Africa in the period 1816-2016 from a black theological perspective. First, the paper describes the black theological perspective from which the inquiry into the story of the Methodist Church of Southern Africa (MCSA) is approached, a perspective which is based on the philosophy of black consciousness, the black liberation theology and Methodist theology. Second, the article offers a black theological reflection on selected figures in the history of the MCSA. As a way of concluding, the article considers the prophetic implications of the heritage of Methodism in the MCSA for the Methodist people today.

Keywords: Methodism; philosophy of black consciousness; black liberation theology; John Wesley; Sefako M. Makgatho; Peter J. Storey; Purity Malinga.

\section{INTRODUCTION}

The Yoruba proverb 'However far a stream flows, it never forgets its origin' highlights the importance of history in both foregrounding an understanding of the present, and navigating the future. Based on the proverb, this article sets out to reflect on aspects of South African church history, specifically on 200 years of the Methodist Church

\section{UNISA}


of Southern Africa's history of existence. In his article titled, 'The black Methodist consultation: From a white perspective', Grassow makes a remarkable point on the need for a discourse on the Methodist Church of Southern Africa (MCSA) becoming a 'truly African church'. ${ }^{1}$ He nuances this point by stating that in ignoring African rhythms and idioms, the Methodist people in Southern Africa betray their African roots. ${ }^{2}$ Although the latter statement rightly upholds the significance of the African heritage, it is inconclusive because many black people in the MCSA employ idioms when preaching and express their spirituality in worship through an African rhythm. The usage of drums, for example, confirms the African expression of spirituality by black people. Obviously, Grassow's view is nuanced from a white perspective, rather than a black one, but the view is plausible. However, the goal of this paper is to offer a black theological assessment of the history of the MCSA. Of significance, therefore, is the point that Grassow embraces the fact that he is located within a black majority country and church. In this social location, he notes that white people in the MCSA experience exclusion because of the blackness of the ethos of the MCSA. ${ }^{3}$ According to Grassow, the use of uniforms, rigid collective organisation, black caucuses, and organisational conventions not only reflect black spirituality but also alienate white people as it is not part of white identity. ${ }^{4}$ At issue here is the view that the ethos of the MCSA has become 'black'. Notwithstanding the need to discuss white identity in the MCSA, the interest of the present article lies in considering the ethos of the MCSA from a black theological perspective.

Although an inquiry into the contribution made by the ministry of Barnabas Shaw to the origins of Methodism in Southern Africa constitutes a critical dimension in the discussion of the heritage of Methodism, this study carries out a black theological reflection on the contributions of Sefako M. Makgatho, Peter Storey and Purity Malinga to the history of the MCSA. The celebration of the 200 years of Methodism in Southern Africa calls for a description of the heritage of Methodism in Southern Africa, specifically from a black theological perspective. Drawing on the literature on Methodism in the Southern African context, this essay focuses on the following points:

- Black theological perspective.

- Reflection on selected Methodists.

- Implications for the MCSA today.

1 Pete Grassow, The black Methodist consultation: From a white perspective, http://rockinthegrass. blogspot.co.za/ (accessed 17 March 2016), 1.

2 Grassow, Black Methodist consultation, 1.

3 Grassow, Black Methodist consultation, 1.

4 Grassow, Black Methodist consultation, 1. 


\section{BLACK THEOLOGICAL PERSPECTIVE OF METHODISM}

Inspired by the contributions of scholars such as Motlhabi, De Gruchy and De Gruchy, West and Tshaka to theological scholarship in South Africa (SA), Mtshiselwa claims that the black liberation theology is inseparable from the philosophy of black consciousness. ${ }^{5}$ In 1971, the University Christian Movement placed in the limelight the black liberation theology in South Africa. The black liberation theology has been linked to the Black Consciousness Movement in South Africa in order to criticise racism. ${ }^{6}$ The philosophy of black consciousness insists on redressing the effects of the oppression of black people in South Africa, which is based on race, while the black liberation theology calls for the liberation of the oppressed people. ${ }^{7}$ A point that is often given insufficient consideration is that the struggle of black South Africans to liberate themselves from the oppression that imbues perpetual servitude, places the burden on the person who assumed the role and identity of servitude. ${ }^{8}$ As Mtshiselwa argues, the philosophy of black consciousness focuses on the oppressed black South Africans who permitted and accepted the situation of oppression, rather than being concerned about the oppressor. ${ }^{9}$ It is clear that this philosophy supports the idea of the liberation of black South Africans from their servitude mentality which caused them to accept their oppression.

On the issue of justice in the context of slavery, Field cites John Wesley's comment on the mentality of the slaves of his time. He notes that 'what the masters experienced as the slaves' stupidity, laziness, stubbornness and wickedness, Wesley described as their "legitimate resistance to slavery". ${ }^{10}$ In a context where violent slave revolts were frequent, Wesley was sympathetic to the idea of resistance to

5 Ndikho Mtshiselwa, The emergence of the black Methodist consultation and its possible prophetic voice in post-apartheid South Africa, HTS Teologiese Studies/Theological Studies 71/3 (2015a): $1-9$.

6 John W. De Gruchy and Steve De Gruchy, The church struggle in South Africa: 25th anniversary edition (London: SCM, 2004), 144-164; Mokgethi Motlhabi, African theology/black theology in South Africa: Looking back, moving on (Pretoria: Unisa Press, 2007), 7; Gerald West, The legacy of liberation theologies in South Africa, with an emphasis on biblical hermeneutics, Studia Historiae Ecclesiasticae 36 (2010): 161; Rothney S. Tshaka, The continued relevance of black liberation theology for democratic South Africa Today, Scriptura 105 (2010a): 540.

7 Cf. Elliot K.M. Mgojo, Prolegomenon to the study of black theology, Journal of Theology for Southern Africa 21 (1977): 28; Steve B. Biko, I write what I like (Johannesburg: Picador Africa, 2004), 49.

8 Biko, I write what I like, 49.

9 Mtshiselwa, Black Methodist consultation, 2015a, 2.

10 David N. Field, Holiness, social justice and the mission of the church: John Wesley's insights in contemporary context, The Journal of Wesley House Cambridge I/2 (2015a): 187; cf. John Wesley, The works of the Rev. John Wesley, M.A., Volume 11. (ed. Thomas Jackson; Grand Rapids: Baker Book House, 1979), 75. 
slavery. ${ }^{11}$ In my view, however, resistance to slavery is synonymous with the rejection of an inferiority complex and a servitude mentality on the part of slaves. Methodism, therefore, is consistent with the philosophy of black consciousness which seeks to liberate the oppressed people from perpetual servitude. The tenor of liberation in both the black liberation theology and philosophy of black consciousness, tallies with John Wesley's theology of the liberty of slaves, among other oppressed persons. Not only did Wesley argue that slavery is inconsistent with mercy and justice, he also claimed that from a justice point of view all humans have the right to be liberated..$^{12}$ In this case, liberty for humans is advocated. Black theology, particularly when premised within the framework of Methodism, shows concern for social justice. Enthused by Methodism, Nyengele argues that a Church inspired by John Wesley's theology regarding the 'works of mercy' is one which pursues justice for the marginalised, excluded and oppressed people in modern societies. ${ }^{13}$ Therefore a concern that is common to Methodism, black liberation theology and philosophy of black consciousness, is the call for social justice, which means the idea of social justice is pivotal to a black theological inquiry into the heritage of Methodism in Southern Africa. It is thus clear that the origins of Methodism in Southern Africa may be taken back to Wesleyan theology, and more importantly that Wesleyan theology is consistent with philosophy of black consciousness, specifically with regards to the concerns for social justice.

Wesleyan theology of mercy, which is grounded on theology of Imago Dei, affirms the dignity and value of all human beings, and more importantly that humans exhibit the image of God. ${ }^{14}$ In a similar vein, not only do the philosophy of black consciousness and black liberation theology refute the negation of blackness, but they also demand that black people in South Africa be treated with pride and dignity. Philosophy of black consciousness rejects the flight from the black self. This is confirmed by Biko's call on black people to come to themselves and to infuse pride and dignity in their worldview. ${ }^{15}$ In continuity with Biko's ideology, Tshaka argues

11 Theodore W. Jennings, Jr. Good news to the poor: John Wesley's evangelical economics (Abingdon: Abingdon Press, 1990), 84.

12 David N. Field, John Wesley as a public theologian: The case of thoughts upon slavery, Scriptura 114/1 (2015b): 4.

13 Fulgence Nyengele, African spirituality and the Wesleyan spirit: Implications for spiritual formation in a multicultural church and culturally pluralistic world, (Paper read at the Practical Theology Section of the Oxford Institute of Methodist Theological Studies, Oxford, England, 2013), 18; cf. Ndikho Mtshiselwa, Surely, goodness and mercy shall follow me... reading Psalm 23:6 in conversation with John Wesley, Studia Historiae Ecclesiasticae 41/2 (2015b): 122; Field, Holiness, social justice, 2015a, 188.

14 Field, Holiness, social justice, 2015a, 192; cf. Wesley, Works of the Rev. John Wesley, 70.

15 Steve B. Biko, I write what I like (London: Heinemann, 1979), 29. 
that the flight from the black self is displayed by the affirmation of whiteness at the expense and rejection of blackness. ${ }^{16}$

Self-hate on the part of black people therefore comes as no surprise because the designation 'black' has been a symbol of ugliness and sinfulness, historically. ${ }^{17}$ The reference to black people as 'monkeys', for instance, continues to render black South Africans as less human, and perpetuates the way black people have been degraded in the colonial and apartheid South Africa. ${ }^{18}$ However, both black philosophers and theologians refute the sense of inferiority, worthlessness, feeling less than human and self-hate among black South Africans that came with the way black people have been historically degraded. Against the reference to black people as 'monkeys' and symbols of ugliness and sinfulness imposed on black South Africans, has arisen a compelling identity undergirded by the idea that 'black is beautiful' and which calls for the restoration of dignity and pride of the oppressed people in the margins of society. ${ }^{19}$ Such an argument offers a liberating image of black people and subsequently provides a theoretical framework within which an interlocutor of black liberation theology may approach modern issues in society.

Worthy of note also is the point that the ethos of blackness does not reject whiteness per se, but white supremacy which places black people at the periphery.

16 Rothney S. Tshaka, On being African and Reformed? Towards an African Reformed Theology enthused by an interlocution of those on the margins of society, HTS Teologiese Studies/Theological Studies 70/1 (2014): 3; cf. Harold Isaacs, Idols of the tribe: Group identity and political change (New York: Harper \& Row, 1975), 127; Cornel West, The Cornel West Reader (New York, NY: Civitas Books, 1999), 305; Rothney S. Tshaka, Do our theological methodologies help us to deal with situations of violence in black communities, specifically Afrophobia, Journal of Theology for Southern Africa 138 (2010b): 124-125; Woody Carter, Theology for a violent age: Religious beliefs crippling African American youth (Bloomington, IN: Universe Books, 2010), 48. For a detail study on the flight from the black self see Donald Woods, Biko (New York: Random House, 1978), 191; Donald Woods, Biko: The true story of the young South African martyr and his struggle to raise black consciousness (New York: Henry Holt Books, 1987), 55; Madipoane Masenya (ngwan'a Mphahlele), An African-conscious female's reading of Steve Biko. In The legacy of Stephen Bantu Biko: Theological challenges (ed. C.W. du Toit; Pretoria: Research Institute for Religion and Theology, University of South Africa, 2008), 120; Mtshiselwa, Black Methodist consultation, 2015a, 1-9.

17 Joseph S. Himes, A theory of racial conflict, Social Forces 50/1 (1971): 55; Graham A. Duncan, Passive-aggressive resistance against apartheid at the Federal Theological Seminary of Southern Africa, Acta Theologica 33/1 (2013): 61-62.

18 Thami Plaatjie, There's only one race, n.p. http://www.sowetanlive.co.za/sowetan/ archive/2009/09/29/there_s-only-one-race (accessed 05 April 2016); Penny Sparrow, Penny Sparrow calls black people 'monkeys', n.p. http:/www.citizen.co.za/wp-content/uploads/ sites/18/2016/01/Penny-Sparow.png?9f116b (accessed 05 April 2016).

19 Mtshiselwa, Black Methodist consultation, 2015a, 5; cf. James H. Cone, Black theology and black power: $20^{\text {th }}$ anniversary edition (New York, NY: Harper and Row, 1989), 151-152; James H. Cone, The blues and the spirituals (Maryknoll, NY: Orbis books, 1992), 21, 53; Dwight N. Hopkins, Heart and head: Black theology, past, present and future (New York: Palgrave, 2002), 54; Tshaka, On being African, 2014, 1, 2. 
The view stems from Biko's observation that South African black people are culpable in respect of the oppression of black people. ${ }^{20}$ Biko refrained from solely accusing white people for being responsible for the struggles of black people, but claimed black people should also be held accountable for their own oppression. Importantly, 'that the philosophy of black consciousness was set to draw to light the way South African black people inflicted their oppression supports the idea of a black ethos which does not reject whiteness'. ${ }^{21}$ The view that Biko's philosophy of black consciousness does not only hold black South Africans accountable for their experience of oppression, but that it also does not entirely hold white people responsible for the oppressive effects of racism on black South Africans, is therefore attractive. ${ }^{22}$ In continuity with Biko's philosophy of black consciousness, as Sobukwe argued, the problem in apartheid South Africa was white domination rather than white people. ${ }^{23}$ Thus, the struggle was not against whites per se, particularly based on the virtue of their colour, but against white supremacy. White supremacy was exhibited in the way the white colonists had dispossessed black people of their ancestral land. The argument ensued from the idea of an ethos of blackness which does not reject whiteness, but rejects the oppression of black South Africans.

In addition, the statement by Sobukwe in 1958 that 'all men shall have rights and freedom merely because they are men' (in Mda's words) validates the view that Sobukwe was not against white people per se, but against racism. ${ }^{24}$ Interestingly, the recurring statement, 'go sin no more' in the gospel which does not condemn a person but the person's action, seems to correspond with Sobukwe's condemnation of the actions of white people, which are entrenched racist laws, rather than the actors. Similarly, Methodism in Southern Africa does not seem to be against white people by the virtue of their colour. The resolution of the MCSA conference of 1958 to be 'one and undivided' shifts the focus from blaming white people for apartheid to working together to build a non-racist society which upholds the dignity of all. ${ }^{25}$ A black theological inquiry into the heritage of Methodism in Southern Africa therefore thrives on the idea of renouncing the oppression of South African black people, rather than condemning white people.

\section{Biko, What I like, 29.}

21 Mtshiselwa, Black Methodist consultation, 2015a, 2.

22 Biko, What I like, 29; cf. Mtshiselwa, Black Methodist consultation, 2015a, 2-3.

23 Plaatjie, There's only one race, n.p.

24 Thomas Karis and Gwendolen M. Carter, From protest to challenge: A documentary history of African politics in South Africa 1882-1964, in Volume 2: Hope and challenges 1935-1952 (ed. by Thomas Karis. Stanford, California: Hoover Institution Press, Stanford University, 1973), 59.

25 Methodist Church of Southern Africa, Minutes of Conference of the Methodist Church of Southern Africa: 1958 (Cape Town: Methodist Publishing House, 1959), 202; cf. Dion Forster, Prophetic witness and social action as holiness in the Methodist Church of Southern Africa's Mission, Studia Historiae Ecclesiasticae 34/1 (2008): 9. 


\section{A BLACK THEOLOGICAL REFLECTION ON THE ACTIVITIES OF SELECTED METHODIST PEOPLE IN SOUTHERN AFRICA}

This article is by and large meant to celebrate the 200 years of Methodism in Southern Africa. What better way is there to celebrate that heritage other than reflecting on the remarkable ministry and activism of Sefako M. Makgatho, Peter J. Storey and Purity Malinga? The focus respectively on a lay preacher, a male white clergy person and a black female clergy person is meant to serve as an inclusive reflection on the heritage of Methodism in Southern Africa. The black theological inquiry into the heritage of Methodism in this article highlights the diversity of the MCSA because the discussion is not confined to racial or gender categories. The black theological reflection teases out ways in which the selected figures sought to redress the oppression of the people in the periphery, sought justice for all people, refuted the perpetual servitude attitude, affirmed the dignity and value of all human beings, attempted to instil pride and dignity in all people, and worked towards a 'one and undivided' MCSA.

\section{Sefako M. Makgatho - lay ministry matters!}

The story of Sefako Mapogo Makgatho, a local Methodist preacher, provides a valuable contribution to the narrative of Methodism in Southern Africa. He was born and bred 'ga Mphahlele' (literally translated as: in the household of the Mphahlele), in the Limpopo Province. As Sechaba has noted, a study of the period 1861-1951 reveals that Makgatho studied education and theology at Ealing, Middlesex, England, among other things. ${ }^{26}$ Viewed in the light of the New Testament text of Ephesians 4, and more importantly of the issue of the participation of all believers in the ministry of Jesus, as well as of the Methodist theology of the 'priesthood of all believers', the legacy of Makgatho in the MCSA is worth considering.

Makgatho's activism and ministry are noticeable in his contributions to the establishment of the South African liberation movement which brought about democracy in South Africa. As Sechaba noted, in response to the 1909 race laws enacted by the Colonial government, Makgatho's activism contributed to the establishment of the African National Congress (ANC) on 8 January 1912. ${ }^{27}$ The establishment of the ANC at that time was clearly a response to the imperialism created by the General A Berlin on 26 February $1885 .{ }^{28}$ Makgatho's fearless criticism of imperialism was denunciation of the oppression of the black people by their white counterpart. From a black theological point of view, specifically with regards to the

26 Tsepho Sechaba, Bibliography: Sefako Mapogo Makgatho, n.p. http://www.anc.org.za/ showpeople.php?p=47 (accessed 08 April 2016).

27 Sechaba, Sefako Mapogo Makgatho, n.p.

28 Sechaba, Sefako Mapogo Makgatho, n.p. 
bid to redress the oppression of the people in the periphery, Makgatho's approach to the pursuit of justice in South Africa appears logical. In a 1919 address, Makgatho said:

Now, ladies and gentlemen, I am told that there is a difference of opinion as to the wisdom of sending a deputation to England. I cannot understand how anyone could call it a crime to send a delegation to the headquarters of the Empire. ${ }^{29}$

It is clear that Makgatho stood in solidarity with the black people who were at the periphery during the colonial period in South Africa. His idea of an ecclesiastic community which is concerned about oppression, tallies with the ideology of liberating black people which is central to the black liberation theology. The case of Makgatho illustrates how a lay leader in the MCSA espoused the idea of refuting the imperialism of the oppressors of the 1900s in South Africa. Of importance, therefore, is a point postulated by Makgatho which President Zuma alluded to in a speech on the occasion of naming the presidential guest house to Sefako Mapogo Makgatho Presidential Guest House. As Zuma noted, Makgatho was in conversation with General Botha and with other Ministers such as Mr Malan, Mr De Wet and $\mathrm{Mr}$ Burton. ${ }^{30}$

It is clear that Makgatho held the view that direct conversations with the oppressors were critical to the discourse of the liberation of black folks. ${ }^{31}$ Any attempt to redress the oppression of black South Africans accords with the black liberation theology as well as Methodism, particularly on the point of denouncing the oppressor. Efforts against oppression ensued from the need to bestow pride and dignity on all human beings, especially the black people who were at the periphery. No doubt, Makgatho's ministry and activism envisioned an ecclesiastical community which seeks to restore the image of God to the oppressed people who had been stripped of their pride and dignity.

In the opening statement of his 1919 ANC presidential address, Makgatho alluded to the point of requesting no special favours from the government. This suggests that all subsequent demands for liberation were not based on a servitude mentality, but an attitude that the oppressed did not seek special favours from the master. ${ }^{32}$ The statement 'we ask for no special favours from the government' is in line with the philosophy of black consciousness, which espouses the rejection of the servitude mentality. As aforementioned, the Methodist ethos that rejects the servitude

29 Sefako M. Makgatho, Presidential address by SM Makgatho, South African Native National Congress, http://www.anc.org.za/show.php?id=4292 (accessed 08 April 2016), 1; cf. Sechaba, Sefako Mapogo Makgatho, n.p.

30 Jacob Zuma, Address by His Excellency President Jacob Zuma, on the occasion of naming the presidential guest house to Sefako Mapogo Makgatho Presidential Guest House, Pretoria, n.p. http://www.thepresidency.gov.za/pebble.asp?relid=6444 (accessed 06 May 2016).

31 Zuma, Makgatho Presidential Guest House, n.p.

32 Makgatho, Presidential address, 1. 
mentality, which was displayed in the slavery industry, is equally noticeable in Makgatho's demand for the liberation of black people from the colonial government. The fact that this lay preacher distanced his ideology from the notion that the oppressed had to curry the favour of the colonial government is commendable, because his statement also affirms the dignity and value of the oppressed.

A point often overlooked in the narrative of Makgatho is his views on genderbased violence, particularly violence against women. In his presidential address of 1919, Makgatho remarked:

...with our women also under the horses' hoof and shot at simply because we say we are not in need of the help that is offered... While our people were shot at and clubbed by civilian whites, and our women-folk ridden down by the mounted police of Johannesburg, there was, at the same time, a strike of well paid white men in the same city, agitating for...Their wives were not ridden down or beaten with sticks. ${ }^{33}$

No doubt, the affirmation of the dignity and value of all human beings which is evident in the rejection of the abuse of women, constitutes a critical dimension of Makgatho's idea of liberation. For Makgatho, therefore, the liberation of black South Africans was meaningless without the liberation of women.

It is clear that in detailing the legacy of Methodism in South Africa the efforts of Makgatho, who was one of the prophetic lay preachers whose ministries are worthy of note, cannot be ignored. Not only did he oppose the oppression of black people who were on the periphery of society, he also affirmed the dignity and value of all human beings, and more importantly of black South Africans, including the women. Makgatho instilled pride and dignity in black South Africans. Thus, he is a notable lay figure in the MCSA whose legacy is compelling.

\section{Peter J. Storey - race matters!}

As mentioned above, a black theological approach - that is grounded on the black liberation theology, philosophy of black consciousness and Methodism - affirms the contributions of both black and white Methodists to the growth of the MCSA. Worthy of note, therefore, is the legacy of Peter Storey, a white Methodist minister whose 40-year ministry in Southern Africa is characterised by the opposition of oppressive racist policies of the apartheid government. ${ }^{34}$

Between 1967 and 1971 when he was a superintendent minister at the Inner City Methodist Mission in Cape Town, Storey 'launched My brother and me, a pioneering diversity training programme for blacks and whites in SA, in order to

33 Makgatho, Presidential address, 1.

34 Peter J. Storey, Curriculum vitae: Peter John Storey, https://divinity.duke.edu/sites/divinity.duke. edu/files/documents/cv/Peter\%20John\%20Storey\%20CV.pdf (accessed 12 April 2016), 2-6. 
integrate the first white members into the District Six congregation' ${ }^{35}$ From 1976 to 1991, Storey was the superintendent minister of the Central Methodist Mission. In his construction of a model for mission in Johannesburg, Peter Storey drew on Alan Walker's model of city mission in the Sydney Central Mission in Australia. ${ }^{36}$ According to Cook, Storey said: 'The moment I heard Alan preach I knew there was a marriage between the personal and the social that rang true to our Methodist roots. He made altar calls and at the same time confronted social evils. ${ }^{37}$ It comes as no surprise, therefore, that in 1976-1991 through his leadership, the Central Methodist Mission (CMM) in Johannesburg began to focus on resistance to apartheid. ${ }^{38}$ That resistance is a decisive contribution to the heritage of Methodism in Southern Africa, mainly because it spurred a revolution against the oppression of the (black) people of God who were placed by the apartheid government on the margins of the society. On the issue of revolution against the sin of apartheid, Storey observed:

The all-white congregation was integrated at the cost of some 200 members and the sanctuary became a centre of protest. CMM hosted numerous anti-apartheid meetings and the church suffered bomb threats and was surrounded many times, tear-gassed, and invaded by security forces. It offered hospitality to the Detainee Support Committee, and housed the Conscription Advice Office and Actstop Tenants Association. CMM also hosted the SA Council of Church's staff for many months after their offices were bombed by a police hit squad in $1988 .{ }^{39}$

Clearly, Storey's activism and prophetic voice are enthused by the Methodist theology of Eucharist, particularly the prayer of thanksgiving that alludes to the unity which the sacrament is calling for among Christians. ${ }^{40}$ According to Storey, the prayer lends credence to the prophetic nature of the Holy Communion. ${ }^{41}$ The unity of people that is suggested by the Holy Communion provides reason for the integration of black and white persons. It is thus clear that division and segregation are inconsistent with the call for unity which is reflected in the Eucharist. ${ }^{42}$ The position held by Sobukwe

35 Storey, Curriculum vitae, 2; cf. Uta Theilen, Gender, race, power, and religion: Women in the Methodist Church of Southern Africa in post-apartheid society, (Unpublished thesis. PhilippsUniversität Marburg, 2003), 33.

36 Jonathan Cook, Peter Storey: Superintendent of the Central Methodist Mission, 1976-1991, (Paper read at the Celebration of the Life and Ministry of Peter J. Storey, Johannesburg, 2016), 2.

37 Cook, Peter Storey, 2.

38 Storey, Curriculum vitae, 2

39 Storey, Curriculum vitae, 2

40 Methodist Conference Office, The Methodist Service Book (London: Methodist Publishing House, 1975), B17.

41 Peter J. Storey, Table manners for peacemakers: Holy Communion in the life of peacemaking. In Conflict and Communion: Reconciliation and restorative justice at Christ's table (ed. Thomas W. Porter; Nashville: Upper Room Ministries, 2006), 57.

42 Wessel Bentley, The reconciliatory role of Holy Communion in the Methodist tradition, (Paper Read at the Conference on Violence in the democratic South Africa: A challenge to theology and the churches. University of Pretoria, Pretoria, 2010), 12-13. 
that black people do not hate white people per se, but racism, supports Storey's advocacy for unity based on the theology of the Holy Communion.

With respect to the legacy of Methodism, Forster writes: 'The Wesleyan heritage has allowed Southern African Methodists to face one of the most dehumanising and destructive systems of abuse in our time, namely, the sin of apartheid. ${ }^{43}$ Although John Wesley said little about race, he was not ignorant of racial abuse. According to Storey, the system of apartheid was synonymous to sin since the apartheid system inflicted injustice and pain on other people. Based on Storey's critique of Wesley's treatment of slavery, it seems that the liberation of slaves implied racial categories. ${ }^{44}$ The slavery of black people in particular was refuted. The view that John Wesley's prophetic voice on the liberty of slaves alludes to social justice is therefore plausible. ${ }^{45}$ In this case, Wesley sought to affirm the dignity and value of slaves who were black in terms of a racial category. Storey's activism therefore stands in continuity with Wesley's stance, which meant to affirm the dignity of the oppressed black people, the so-called people of colour. Storey's attempts to unify white and black South Africans were inspired perhaps by the idea of restoring the dignity of the black people who were placed at the periphery by the dual system of colonialism and apartheid.

In 1981, Storey served as the chairperson of the 'Message Committee' which facilitated and formulated the 'message' of Obedience ' 81 . At that time, the national gathering of Methodists was invited to stake out the position of MCSA in the midst of a deepening apartheid crisis. ${ }^{46}$ At the gathering, where Storey was also a plenary speaker, the Methodist people openly pledged themselves to seek unity within the church in the context of apartheid. ${ }^{47}$ In 1981 the MCSA held a conference which later came to be known as Obedience ' $81 .{ }^{48}$ The Conference made a declaration of its conviction 'that it is the will of God for the Methodist Church that it should be one and undivided'. This was a re-affirmation of the 1958 Conference decision that the church should be 'one and undivided' in opposition to the apartheid state's intentions to segregate the nation, and the church. The adoption of this motto expressed a clear intent to keep people of different races, ethnic groups and cultural backgrounds united within the MCSA. The Obedience ' 81 decision came at the height of the oppressive and violent enactment of apartheid in South Africa. In this context, the 'message' of Obedience ' 81 contained a critical prophetic call for unity and justice. ${ }^{49}$

43 Forster, Prophetic witness and social, 7.

44 Peter J. Storey, And are we yet alive? Revisioning our Wesleyan heritage in the new Southern Africa (Cape Town: Methodist Publishing House, 2004), 77.

45 Storey, And are we yet alive, 78.

46 Storey, Curriculum vitae, 3.

47 Forster, Prophetic witness and social, 13.

48 Storey, And are we yet alive, 79; cf. Forster, Prophetic witness and social, 14.

49 Storey, And are we yet alive, 79; cf. Forster, Prophetic witness and social, 14. 
Evidently, Storey's valuable contribution to Methodism in Southern Africa is embodied in his call for transformation and justice. ${ }^{50} \mathrm{He}$ viewed the church as an agent of transformation and justice. Therefore, it is important to highlight Storey's conviction that at the heart of the unity of black and white people was the call for justice. The call for unity is inseparable from the pursuit of transformation and justice for all human beings.

\section{Purity Malinga - Gender matters!}

At the time when 'there were three white and two black women in the ministry throughout the connexion', Purity Malinga, who was born in Ixopo in the KwaZuluNatal Province, was ordained into ministry by the Conference of 1981 at the Natal West Synod. ${ }^{51}$ In that context, there was resistance against the ordination of women ministers particularly by circuits and ministers. The opposition to female ordination was not born out of biblical or theological, but rather cultural values. ${ }^{52}$ In her recommendation of Malinga for appointment to the post of directorship of Education for Ministry and Mission Unit (EMMU), Lebaka-Ketshabile says:

Purity has circuit experience and that of the training and formation of MCSA's ministers in training. She has taught at (Federal Theological Seminary of Southern Africa) FEDSEM and John Wesley College - the two institutions that have been critical in forming ministers for the MCSA. Further, Rev. Malinga has District Management experience. She is the only woman in the Methodist Church of Southern Africa to have been elected a Bishop, a position she served for nine years with humility and simplicity required for the position. ${ }^{53}$

A minister who occupies the office of the District Bishop is defined as one who 1) 'is the official head of the District and is subject to the directions of Conference and the Laws and usages of the Church', and 2) 'is the principal pastor and official head of a District and is to exercise his/her duties in the spirit of servant-leadership that

50 Storey, And are we yet alive, 44-46; Peter J. Storey, Banning the flag from our churches: Learning from the church-state struggle in South Africa. In Between capital and cathedral: Essays on church-state state relationships (ed. W. Bentley \& D.A. Forster; Pretoria: Research Institute for Theology and Religion, 2012), 15; cf. Wessel Bentley, Methodism and transformation in South Africa: 20 Years of constitutional democracy, HTS Teologiese Studies/Theological Studies 70/1 (2014): 7.

51 Purity Malinga, 40 years of ordained women in the MCSA ministry, (Paper read at the Limpopo District Women's Manyano Convention held at Middelburg, 2016), 5; cf. Nelson Dlamini, Bishop Malinga hands over reins, n.p. http://www.iol.co.za/news/south-africa/bishop-malinga-handsover-reins-421820 (accessed 11 April 2015); Cf. Sandra, Hayes, Who's who of Southern Africa 2001 (Graighall: Jonathan Ball, 2012), 1.

52 Malinga, 40 years of ordained women, 5.

53 Libuseng S. Lebaka-Ketshabile, Professional reference in respect of Rev. Purity Malinga: Director EMMU, (Unpublished professional reference. Pretoria, 2015), 1; cf. Dlamini, Malinga hands over reins, n.p. 
was taught and modelled by our Lord Jesus Christ, among others'. ${ }^{54}$ Among other functions she fulfilled, Malinga became a mission-driven leader, principal pastor, custodian of unity, overseer of the training and development of clergy and laity and facilitator of the prophetic function of the church..$^{55}$

On the issues of social justice, one incident that is worth mentioning is Malinga's denunciation of the recent xenophobic attacks in South Africa. She argued that black people in particular ' had abandoned an African philosophy which is encapsulated in the African philosophy of Ubuntu'. ${ }^{56}$ The criticism of xenophobic attacks, which was enthused by the African philosophy of Ubuntu, tallies with the idea of affirming the dignity and value of all human beings. Thus, from a black theological perspective, Malinga's rejection of xenophobic attacks is remarkable. According to Dlamini, Malinga argued that not only were the xenophobic attacks enthused by baseless hatred which the MCSA witnessed, but were also irrational. ${ }^{57}$ Given the MCSA's ethos of 'one and undivided', Malinga's call for love which refutes hatred comes as no surprise. It is clear that Malinga extended the Lordship of Christ to people of foreign nationality in order to instil dignity and redress the violence against people from countries outside of South Africa.

It is commendable that Malinga led a campaign to encourage church ministers to know their HIV status by personally undergoing a public HIV/Aids test in May of 2008. At that time, and even now, it was reported that Malinga called the government to address societal issues such as HIV/Aids, poverty, moral regeneration and healthcare.$^{58}$ In addition, from 2002 to 2006, Malinga served as a trustee of the Church Community Leadership Trust and subsequently facilitated the project, 'Moral Leadership for Social Transformation'. ${ }^{59}$ Malinga espoused the value of ethical leadership which is grounded on the principle of integrity. As noted above, key values of the philosophy of black consciousness, black liberation theology and Methodist theology, include redressing oppression of the past; pursuing justice for all people; the rejection of perpetual servitude attitude; the affirmation of the dignity and value of all human beings; and building of a 'one and undivided' MCSA. Thus, based on Malinga's ethos of ethical leadership, these key values seem to centre around the principle of integrity on the part of leaders.

Malinga's story provides evidence of efficient leadership by a woman minister in the MCSA. In our patriarchal African cultures, women are mostly viewed as unable to lead. The Sepedi/Northern Sotho proverb Tša etwa ke ye tshadi pele, di

54 The Methodist Church of Southern Africa, Laws and Discipline. 11th Edition (Woodstock: Salty Print, 2007), 71.

55 Methodist Church of Southern Africa, Laws and Discipline, 72.

56 Dlamini, Malinga Hands over reins, n.p.

57 Dlamini, Malinga Hands over reins, n.p.

58 Dlamini, Malinga Hands over reins, n.p.

59 Purity Malinga, Curriculum vitae: Purity Malinga, (Unpublished Curriculum vitae. Pretoria, 2015), 2. 
wela ka leope [literally translated as: 'Once they are led by a female one, that is, a cow, they will fall into a donga'], confirms this. That a donga refers to a short dried up river which does not have the potential to produce life, suggests that leadership by a female figure, like a proverbial cow, would land 'them' in trouble. ${ }^{60}$ The preceding view is based on the perception that women are powerless and are incapable to lead. However, given the fact that Malinga leads the Methodist people in the MCSA, the tenor of the preceding proverb needs to be problematised. The story of Malinga provides convincing evidence that a woman minister has indeed offered leadership which did not and has not led the MCSA into a donga of destruction.

\section{CONCLUDING REMARKS: IMPLICATIONS FOR THE MCSA TODAY}

The issue of gender continues to matter in the MCSA today. In her report to the 2015 conference of the Methodist Church of Southern Africa (MCSA), the General Secretary, Reverend Charmaine Morgan remarked:

Starting now, we celebrate the Year of celebrating Women Clergy. 40 years after the Ordination of the first woman as a minister, $17 \%$ of our clergy are women, $4 \%$ of our Superintendents are women, and no women are Bishops. We will celebrate our victories in the coming year in various ways, but we still have a far way (sic) to go before we can say we have achieved our goals..$^{61}$

From Morgan's remark above, it is clear that the unjust dominance of masculinity continues to be a challenge to many clergywomen in the MCSA. A case in point is the problem of patriarchy. Statistics cited by Morgan reveal that in a church which is male dominated such as the MCSA, women are oppressed and deprived of being in leadership positions. It is puzzling that after 40 years of the existence of women clergy in the MCSA, there is presently no minister serving at the office of the District Bishop and that women merely constitute four per cent of superintendents. One wonders why the (Southern) African people are sceptical about female leadership, and more importantly in the MCSA. The patriarchal society of Southern Africa, in which the MCSA operates, continues to disempower women. This is a point to lament. However, there is a need to celebrate the progress made on righting the wrongs of patriarchy - unjust dominance of masculinity - in the MCSA. As Morgan correctly observed, the fact that 17 per cent of our clergy are women suggests that at the local level, women have assumed leadership roles. Although the legacy of

60 Joseph R. D. Rakoma, Marema-ka-dika tša Sesotho sa Leboa (Pretoria: Van Schaik, 1970), 222; V. Ndikhokele N. Mtshiselwa and Madipoane Masenya (ngwan'a Mphahlele), South African female presidential leadership and the inevitability of a donga as final destination? Reading the Deuteronomistic Athaliah the Bosadi way, Verbum et Ecclesia 37/2 (2016): 1, 3.

61 Charmaine Morgan, The General Secretary's Report to Conference 2015, in 2016 Yearbook (ed. The Methodist Church of Southern Africa; Cape Town: Methodist Publishing House, 2016), 21. 
enduring patriarchy is lamentable, the progress made in affirming the leadership of women equally deserves commendation and celebration, which means that we find ourselves dangling between celebration and lament. On the issue of the present challenges that female clergy experience in present day South Africa, Malinga ${ }^{62}$ raises three issues of concern:

- The general resistance to women's leadership in the MCSA is unacceptable. The only leadership role that women play without opposition is being a Class Leader, and the abuse and rejection of women in leadership and in ministry continues.

- Policy on gender representation has not led to practice in circuits, Districts and Connexions.

- The leadership model of the black church continues to ignore clergywomen as well as leadership capabilities of women. This issue tends to be discussed with emotion and without people actually hearing one another. As long as there are positions of leadership that are reserved for some people, or a particular gender, the church is denying itself the possibility of operating in excellence.

Malinga $^{63}$ also calls on the MCSA to:

- Engage in open discussions about how our patriarchal cultures distort our humanity and our discipleship. All of us, women and men, contribute to the devaluation of women in church and in society.

- Open ourselves to unlearning gender biases and teach our children such (through workshops).

- Ensure the implementation of gender representation at all levels of church structure.

A pivotal question to ask is: What lessons can we draw from the legacy of Peter $\mathrm{J}$. Storey? Building on Storey's views, Bentley argues that after the first democratic elections of 1994 in South Africa, the MCSA's commitment to social change floundered. ${ }^{64}$ In other words, the prophetic voice and relevance of the MCSA weakened. Storey credits this general lull in social mission by the Christian Church in South Africa to several factors which include; the silence of some church voices, the relationship of some clergy persons with the government, as well as the hope on the part of the older clergy that the younger generation would further advance the struggle for liberation. ${ }^{65}$ Based on Wesley's conviction that Methodist people should

62 Malinga, 40 years of ordained women, 10.

63 Malinga, 40 years of ordained women, 12.

64 Bentley, Methodism and transformation, 2014, 4.

65 Storey, Banning the flag, 15. 
pursue transformation and justice, the present generation of both clergy and laity needs to draw lessons from Storey's ministry ${ }^{66}$

As aforementioned, Grassow has noted the feeling of exclusion by white Methodists as the ethos of the MCSA has become mainly black. ${ }^{67}$ Whether Grassow's view is valid, is beside the point. It is important, however, to re-iterate Storey's call for integration as well as the message of Obedience '81, namely the 'one and undivided church'. Furthermore, in a society where the racial rhetoric that black people are 'monkeys' is evident, the call for love, respect and unity among people of different race becomes critical. However, reconciliation and unity become pointless when issues of socio-economic injustice or economic inequalities - created by the apartheid government and land dispossession - and which adversely affect black people, are not addressed. ${ }^{68}$

The celebration of 200 years of Methodism in Southern Africa, which highlights the stories of Sefako M. Makgatho, Peter J. Storey, Purity Malinga, no doubt confirms the Yoruba proverb which says: 'However far a stream flows, it never forgets its origin.' The black theological perspective through which an inquiry into the story of the MCSA is made, teased out a variety of factors which are worth considering. Such factors are, but are not limited to: 1) Redressing the effects of the oppression of the black people; 2) Rejection of perpetual servitude attitude; 3) Affirmation of the dignity and value of all human beings; 4) Instillation of pride and dignity in all people; and 5) Pursuit of a 'one and undivided' MCSA. These factors bear prophetic implications for the heritage of Methodism in the MCSA for the Methodist people today. The Yoruba proverb 'However far a stream flows, it never forgets its origin', thus gives credence to the argument that a prophetic voice for present-day South Africa, may well be drawn from the history of the MCSA.

\section{REFERENCES}

Bentley, W. 2010. The reconciliatory role of Holy Communion in the Methodist tradition. Paper Read at the Conference on violence in the democratic South Africa: A challenge to theology and the churches. University of Pretoria, Pretoria.

Bentley, W. 2014. Methodism and transformation in South Africa: 20 years of constitutional democracy. HTS Teologiese Studies/Theological Studies 70(1): 1-8.

Biko, Steve B. I write what I like. 1979. London: Heinemann.

Biko, Steve B. I write what I like. 2004. Johannesburg: Picador Africa.

66 Cf. Storey, And are we yet alive, 44-46; Bentley, Methodism and transformation, 2014, 7.

67 Grassow, Black Methodist consultation, 1.

68 Tshepo Lephakga, Reclaiming God and reclaiming dignity: The history and future of black liberation from internalised oppression, Studia Historiae Ecclesiasticae 38/2 (2012): 65-80; Tshepo Lephakga, Dealing with the wounds of my people lightly: A theological ethical critique of the South African Truth and Reconciliation Commission, (Unpublished Thesis, Pretoria, 2015). 
Carter, W. 2010. Theology for a violent age: Religious beliefs crippling African American youth. Bloomington, IN: Universe Books.

Cone, J.H. 1989. Black theology and black power: $20^{\text {th }}$ anniversary edition. New York, NY: Harper and Row.

Cone, J.H. 1992. The blues and the spirituals. Maryknoll, NY: Orbis Books.

Cook, J. 2016. Peter Storey: Superintendent of the Central Methodist Mission, 1976-1991. Paper read at the celebration of the life and ministry of Peter J. Storey, Johannesburg, 2016.

De Gruchy, J.W. and De Gruchy, S. 2004. The church struggle in South Africa: $25^{\text {th }}$ anniversary edition. London: SCM.

Dlamini, N. Bishop Malinga hands over reins. n.p. http://www.iol.co.za/news/south-africa/bishopmalinga-hands-over-reins-421820 (accessed 11 April 2015).

Duncan, G.A. 2013. Passive-aggressive resistance against apartheid at the Federal Theological Seminary of Southern Africa. Acta Theologica 33/1: 54-78.

Field, David N. 2015a. Holiness, social justice and the mission of the church: John Wesley's insights in contemporary context. The Journal of Wesley House Cambridge I(2): 177-198.

Field, David N. 2015b. John Wesley as a public theologian: The case of thoughts upon slavery. Scriptura 114(1): 1-13.

Forster, D. 2008. Prophetic witness and social action as holiness in the Methodist Church of Southern Africa's Mission. Studia Historiae Ecclesiasticae 34(1): 1-24.

Grassow, P. The black methodist consultation: From a white perspective. http://rockinthegrass. blogspot.co.za/ (accessed 17 March 2016).

Hayes, S. 2012. Who's who of Southern Africa 2001. Graighall: Jonathan Ball.

Himes, J.S. 1971. A theory of racial conflict. Social Forces 50(1): 53-60.

Hopkins, D.N. 2002. Heart and head: Black theology, past, present and future. New York: Palgrave.

Isaacs, H. 1975. Idols of the tribe: Group identity and political change. New York: Harper \& Row.

Jennings, T.W. 1990. Good news to the poor: John Wesley's evangelical economics. Abingdon: Abingdon Press.

Karis, T. and Carter, G.M. 1973. From protest to challenge: A documentary history of African politics in South Africa 1882-1964. In Hope and Challenges 1935-1952 (volume 2). Edited by T. Karis. Stanford, California: Hoover Institution Press, Stanford University.

Lebaka-Ketshabile, L.S. 2015. Professional reference in respect of Rev. Purity Malinga: Director EMMU. Unpublished professional reference. Pretoria.

Lephakga, T. 2012. Reclaiming God and reclaiming dignity: The history and future of black liberation from internalised oppression. Studia Historiae Ecclesiasticae 38(2): 65-80.

Lephakga, T. 2015. Dealing with the wounds of my people lightly: A theological ethical critique of the South African Truth and Reconciliation Commission. Unpublished Thesis, Pretoria.

Makgatho, S.M. Presidential address by SM Makgatho, South African Native National Congress. Pages 1-5. http://www.anc.org.za/show.php?id=4292 (accessed 08 April 2016).

Malinga, P. 2015. Curriculum vitae: Purity Malinga. Unpublished Curriculum vitae. Pretoria. 
Malinga, P. 2016. 40 years of ordained women in the MCSA Ministry. Paper Read at the Limpopo District Women's Manyano Convention, Middelburg.

Masenya (ngwan'a Mphahlele), M. 2008. An African-conscious female's reading of Steve Biko. In The legacy of Stephen Bantu Biko: Theological challenges, pp. 114-155. Edited by C.W. du Toit. Pretoria: Research Institute for Religion and Theology, University of South Africa.

Methodist Church of Southern Africa. 1959. Minutes of Conference of the Methodist Church of Southern Africa: 1958. Cape Town: Methodist Publishing House.

Methodist Conference Office. 1975. The Methodist Service Book. London: Methodist Publishing House.

Mgojo, E.K.M. 1977. Prolegomenon to the study of black theology. Journal of Theology for Southern Africa 21: 25-32.

Morgan, C. 2016. The General Secretary's Report to Conference 2015. In 2016 Yearbook, pp. 1626. Edited by The Methodist Church of Southern Africa. Cape Town: Methodist Publishing House.

Motlhabi, M. 2007. African theology/black theology in South Africa: Looking back, moving on. Pretoria: Unisa Press.

Mtshiselwa, N. 2015a. The emergence of the black Methodist consultation and its possible prophetic voice in post-apartheid South Africa. HTS Teologiese Studies/ Theological Studies 71(3): 1-9.

Mtshiselwa, N. 2015b. Surely, goodness and mercy shall follow me... reading Psalm 23:6 in conversation with John Wesley. Studia Historiae Ecclesiasticae 41(2): 116-130.

Mtshiselwa, V.N. and Masenya (ngwan'a Mphahlele), M. 2016. South African female presidential leadership and the inevitability of a donga as final destination? Reading the Deuteronomistic Athaliah the Bosadi way, Verbum et Ecclesia 37(2): 1-8.

Nyengele, F. 2013. African spirituality and the Wesleyan spirit: Implications for spiritual formation in a multicultural church and culturally pluralistic world. Paper read at the Practical Theology Section of the Oxford Institute of Methodist Theological Studies, Oxford, England.

Plaatjie, T. There's only one race. n.p. http://www.sowetanlive.co.za/sowetan/archive/2009/09/29/ there_s-only-one-race (accessed 5 April 2016).

Rakoma, J.R.D. 1970. Marema-ka-dika tša Sesotho sa Leboa. Pretoria: Van Schaik.

Sechaba, T. Bibliography: Sefako Mapogo Makgatho. n.p. http://www.anc.org.za/showpeople. php?p=47 (accessed 08 April 2016).

Sparrow, P. Penny Sparrow calls black people 'monkeys'. n.p. http://www.citizen.co.za/wpcontent/uploads/sites/18/2016/01/Penny-Sparow.png?9f116b (accessed 05 April 2016).

Storey, P.J. 2004. And are we yet alive? Revisioning our Wesleyan heritage in the new Southern Africa. Cape Town: Methodist Publishing House.

Storey, P.J. 2006. Table manners for peacemakers: Holy Communion in the life of peacemaking. In Conflict and Communion: Reconciliation and restorative justice at Christ's table. Edited by T.W. Porter. Nashville: Upper Room Ministries.

Storey, P.J. 2012. Banning the flag from our churches: Learning from the church-state struggle in South Africa. In Between capital and cathedral: Essays on church-state state relationships, pp.1-20. Edited by W. Bentley and D.A. Forster. Pretoria: Research Institute for Theology and Religion. 
Storey, P.J. Curriculum vitae: Peter John Storey. Pages 1-14. https://divinity.duke.edu/sites/ divinity.duke.edu/files/documents/cv/Peter\%20John\%20Storey\%20CV.pdf (accessed 12 April 2016).

The Methodist Church of Southern Africa. 2007. Laws and Discipline (11 ${ }^{\text {th }}$ edition). Woodstock: Salty Print.

Theilen, U. 2003. Gender, race, power, and religion: Women in the Methodist Church of Southern Africa in post-apartheid society. Unpublished thesis. Philipps-Universität Marburg.

Tshaka, R.S. 2009. Academic theology as the yardstick of being Reformed in South Africa today: An appreciative critique of Calvin on the occasion of his $500^{\text {th }}$ birthday. Studia Historiae Ecclesiasticae 35: 1-16.

Tshaka, R.S. 2010a. The continued relevance of black liberation theology for democratic South Africa Today. Scriptura 105: 532-546.

Tshaka, R.S. 2010b. Do our theological methodologies help us to deal with situations of violence in black communities, specifically Afrophobia. Journal of Theology for Southern Africa 138: 124-135.

Tshaka, R.S. 2014. On being African and Reformed? Towards an African Reformed theology enthused by an interlocution of those on the margins of society. HTS Teologiese Studies/ Theological Studies 70(1): 1-7.

Wesley, J. 1997. The works of the Rev. John Wesley, M.A., Volume 11. Edited by Thomas Jackson. Grand Rapids: Baker Book House.

West, C. 1999. The Cornel West reader. New York, NY: Civitas Books.

West, G. 2010. The legacy of liberation theologies in South Africa, with an emphasis on biblical hermeneutics. Studia Historiae Ecclesiasticae 36: 157-183.

Woods, D. 1978. Biko. New York: Random House.

Woods, D. 1987. Biko: The true story of the young South African martyr and his struggle to raise black consciousness. New York: Henry Holt Books.

Zuma, J. Address by His Excellency President Jacob Zuma, on the occasion of naming the presidential guest house to Sefako Mapogo Makgatho Presidential Guest House, Pretoria. n.p. http://www.thepresidency.gov.za/pebble.asp?relid=6444 (accessed 06 May 2016). 